\title{
Microstructure and Properties of Elektron 21 Magnesium Alloy
}

\author{
Andrzej Kiełbus \\ Silesian University of Technology \\ Poland
}

\section{Introduction}

Magnesium is the lightest of metals used for constructional alloys. These alloys are characterised by low density and good mechanical properties (Mordike et al., 2001), however they are showed poor properties in elevated temperature (Mordike, 2002). Among various magnesium alloys, rare earth containing alloys are known to show good mechanical properties and excellent creep resistance (Avedesian et al., 1994). Mainly for these reasons, magnesium alloys have a widespread application in the motor vehicle and aircraft industries. The disadvantages are poor properties in elevated temperatures and high reactivity (Mordike, 2001). A range of alloys are commercially available from $\mathrm{Mg}$-Al alloys to highest strength, high temperature $\mathrm{Mg}-\mathrm{Zr}$ alloys with addition of yttrium. However alloys that contain yttrium have high associated cost due the difficulties in casting. Therefore there is a need for an alternative alloy which has similar properties to $\mathrm{Mg}-\mathrm{Y}$ alloys, but with foundry handling and associated costs like non-yttrium containing alloys (Lorimer et al., 2003).

Magnesium alloys containing neodymium and gadolinium are interesting as light structural materials with high mechanical properties at room and elevated temperatures (Smola et al., 2002). Mg-Nd-Gd-Zr magnesium alloys are characterised by high-strength and good creep resistance to automotive and aerospace applications (Rokhlin et al., 1996). The rare earth elements have beneficial effect of on the creep properties, thermal stability of structure and mechanical properties of magnesium alloys (He et al., 2006).

Elektron 21 is new magnesium based casting alloy containing neodymium, gadolinium and zinc for used to approximately $200^{\circ} \mathrm{C}$. This alloy has high strength, good corrosion resistance and excellent castability. Neodymium has a positive effect on tensile strength at elevated temperature, reduces porosity of casts and susceptibility to cracking during welding. Gadolinium, like neodymium shows a decreasing solid solubility as temperature falls, indicating potential for precipitation strengthening. Addition neodymium to $\mathrm{Mg}-\mathrm{Gd}$ alloys reduces the solid solubility of gadolinium. It improves precipitation hardening response, at lower levels of gadolinium than the binary system offers. Zinc is added to magnesium alloys in sufficient quantities to achieve precipitation strengthening. It improves strength without reducing ductility. Zirconium, which does not form any phases with magnesium or alloying elements, contributes to the obtaining of a fine grain structure and improves the mechanical properties at an ambient temperature, castability and corrosion performance. Elektron 21 is being used in both civil and military aircraft and also in automobile (motorsport) industry (Lyon et al., 2005). 
The scope of this book chapter is to provide the results of microstructure, mechanical properties, creep and corrosion investigations of Elektron 21 magnesium alloy in as-cast condition and after heat treatment.

\section{Material and methodology}

The material for the research was a sand casting Elektron 21 magnesium alloy. The chemical composition of this alloy is provided in Table 1.

\begin{tabular}{|c|c|c|c|c|c|c|c|c|}
\hline $\mathrm{Gd}$ & $\mathrm{Nd}$ & $\mathrm{Zr}$ & $\mathrm{Zn}$ & $\mathrm{Mn}$ & $\mathrm{Fe}$ & $\mathrm{Ag}$ & $\mathrm{TRE}$ & $\mathrm{Mg}$ \\
\hline 1,2 & 2,7 & 0,49 & 0,4 & 0,001 & 0,003 & 0,01 & 4,2 & balance \\
\hline
\end{tabular}

Table 1. Chemical composition of the Elektron 21 alloy (wt.\%).

Sand casting was performed at 730,780 and $830^{\circ} \mathrm{C}$ temperature. Castability has been investigated by determining the flow length with a mould featuring a spiral shaped cavity. The as-cast specimens were solution treated at $520{ }^{\circ} \mathrm{C}$ for $2 \div 48 \mathrm{~h}$ and quenched into water. Ageing treatments were performed at $200^{\circ} \mathrm{C}, 250^{\circ} \mathrm{C}$ and $300^{\circ} \mathrm{C} / 4 \div 5000 \mathrm{~h}$ with cooling in air. Thermal diffusivity was measured on LFA 427 Netzsch apparatus. The measurement was performed in the temperature range from 25 to $300^{\circ} \mathrm{C}$. The temperature was increased from ambient temperature to each test temperature (step $25^{\circ} \mathrm{C}$ ). Thereafter, the thermal diffusivity measurement was carried out under isothermal conditions. The temperature of the rear surface of the specimen was measured with an InSb IR detector. Thermal diffusivity was calculated using the relation:

$$
\alpha=0,1388 \frac{\mathrm{g}^{2}}{\mathrm{t}_{0,5}}
$$

where:

$\mathrm{g}$ - is the thickness of the specimen, $\mathrm{t}_{0,5}$ - half- rise time, defined as the interval required for the rear surface temperature to reach one- half of the maximum temperature increase.

For the microstructure observation, an OLYMPUS GX71 metallographic microscope and a HITACHI S-3400N scanning electron microscope were used. TEM examination was carried out on a Tecnai $\mathrm{G}^{2}$ transmission electron microscope equipped with a high-angle annular dark-field detector and energy dispersive $\mathrm{X}$-ray spectrometer.

For a quantitative description of the structure, stereological parameters describing the size and shape of the solid solution grains and phase precipitates were selected. To measure the stereological parameters, a program for image analysis "MET-ILO" was used. The procedure of converting the input image into a binary image to be used for grain size measurement is presented in Fig.1 and for intermetallic phase precipitates in Fig.2.

The examination of the mechanical properties was conducted on an MTS-810 machine at ambient (ca. $20^{\circ} \mathrm{C}$ ) and $200^{\circ} \mathrm{C}$ temperature. Hardness tests have been performed with a Vickers indenter. Constant-load tensile creep tests were performed at $200^{\circ} \mathrm{C}$ and $250^{\circ} \mathrm{C}$ in the stress range $90 \div 150 \mathrm{MPa}$. Creep strain was measured by extensometers which were attached directly to the gauge section of specimens.

For corrosion test the specimens were exposed for 7 days to $3.5 \% \mathrm{NaCl}$ saturated with $\mathrm{Mg}(\mathrm{OH})_{2}$ solution maintained at ambient temperature, without stirring. Before the tests, the specimens were polished with $\mathrm{SiC}$ papers up to 1200 grit. After cleaning with acetone and 


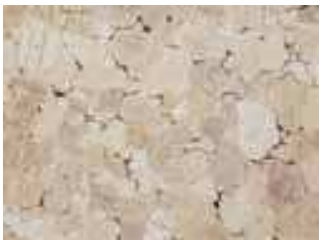

Picture A

gray image

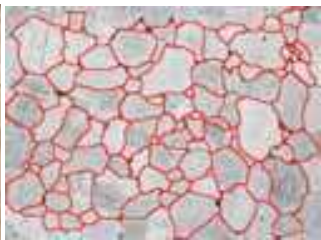

Picture B normalization, shadow correction, detection

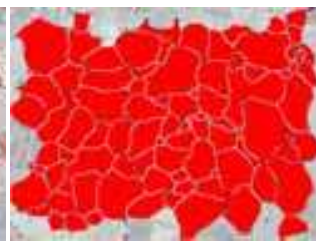

Picture C negative, edge removal

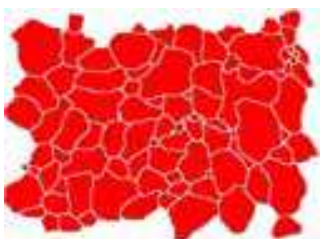

Picture D

manual correction,

image for measurement

Fig. 1. The procedure of a quantitative evaluation of solid solution a-Mg grains in Elektron 21 alloy, LM.

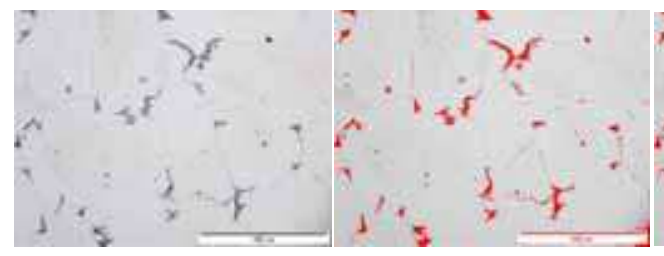

Picture A

gray image
Picture B

normalization, shadow correction, binarisation

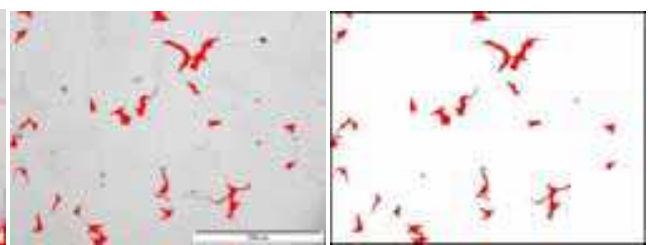

Picture D

Picture C

manual correction image for measurement

Fig. 2. The procedure of a quantitative evaluation of intermetallic phases precipitates in Elektron 21 alloy, LM.

drying, they were weighed to obtain their original weight $\left(\mathrm{m}_{\mathrm{o}}\right)$ before corrosion. After immersion test, the corroded specimens were taken out of the solution, cleaned with distilled water and dried. They were then immersed in chromate acid $\left(200 \mathrm{~g} / \mathrm{dm}^{3} \mathrm{CrO}_{3}+\right.$ $10 \mathrm{~g} / \mathrm{dm}^{3} \mathrm{AgNO}_{3}$ ) to remove corrosion products. After that, the specimens were cleaned again with distilled water, rinsed with acetone and dried. The specimens were weighed on an analytical balance to an accuracy of $\pm 0.1 \mathrm{mg}$. The dried specimens were weighed $\left(\mathrm{m}_{1}\right)$ after immersion. The difference between $\mathrm{m}_{\mathrm{o}}$ and $\mathrm{m}_{1}$ is the corrosion weight loss $(\Delta \mathrm{m})$. According the test results, the corrosion rate was calculated.

\section{Results}

\subsection{As-cast state}

The Elektron 21 alloy composed mainly of a solid solution structure $\alpha-\mathrm{Mg}$ with eutectic $\alpha-\mathrm{Mg}+\mathrm{Mg}_{3}(\mathrm{Nd}, \mathrm{Gd})$ on the grain boundaries. The $\mathrm{Mg}_{3}(\mathrm{Nd}, \mathrm{Gd})$ phase (Fig. 3a) is a modification of $\mathrm{Mg}_{3} \mathrm{Nd}$ phase with neodymium substituted by gadolinium without destroying the crystal structure, due to reasonably small difference in the atomic radii between gadolinium $\mathrm{r}_{\mathrm{Gd}}=0,1802 \mathrm{~nm}$ and neodymium $\mathrm{r}_{\mathrm{Nd}}=0,1821 \mathrm{~nm}$. The regular precipitates of $\mathrm{MgGd}_{3}$ phase have been also observed (Fig. $3 \mathrm{~b}$ ).

A quantitative evaluation of the Elektron 21 alloy microstructure has shown that the mean area of the solid solution $\mathrm{a}-\mathrm{Mg}$ grain equals $\overline{\mathrm{A}}=649 \mu \mathrm{m}^{2}$, and the mean shape coefficient 
value equals $\xi=4 \Pi \mathrm{A} / \mathrm{P}^{2}=0.64$. The mean surface fraction of intermetallic phase, is $\mathrm{V}_{\mathrm{V}}=6.55 \%$, whereas the mean shape coefficient value is $\xi=0.53$.

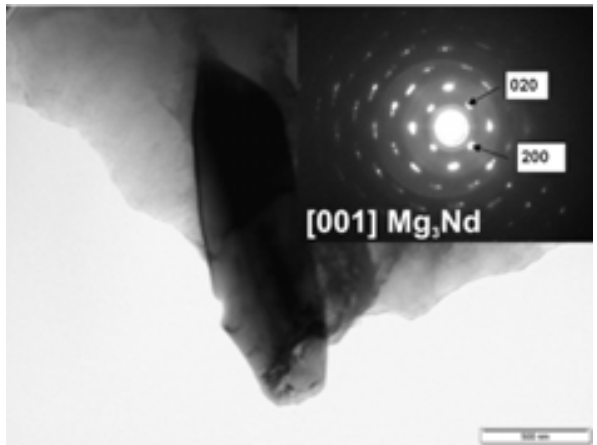

(a)

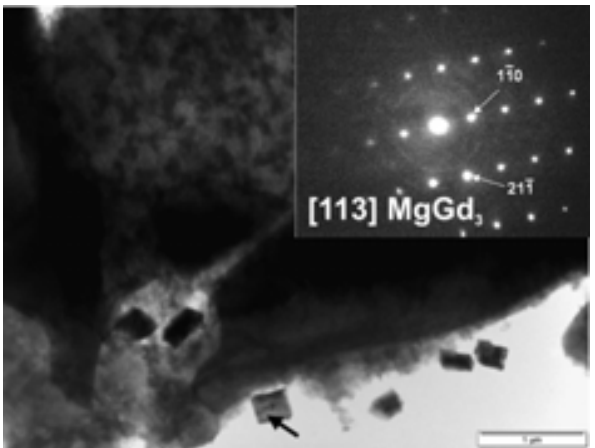

(b)

Fig. 3. Microstructure of the Elektron 21 alloy in as-cast condition:

a) TEM image and corresponding diffraction pattern of $\mathrm{Mg}_{3} \mathrm{Nd}$ phase

b) TEM image and corresponding diffraction pattern of $\mathrm{MgGd}_{3}$ phase.

\subsection{Castability}

The castability of Elektron 21 alloy increase with the increase of casting temperature over the whole temperature range. Spiral casts of Elektron 21 alloy after casting from temperature 730, 780 and $830^{\circ} \mathrm{C}$ were showed in Fig. 4 .

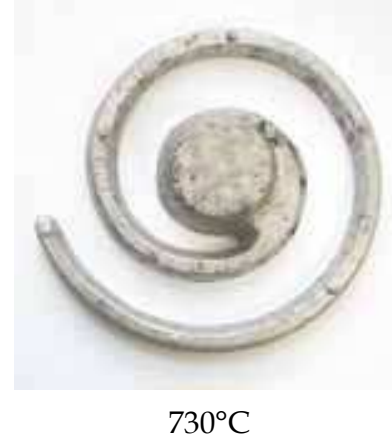

Spiral length $-0,47 \mathrm{~m}$

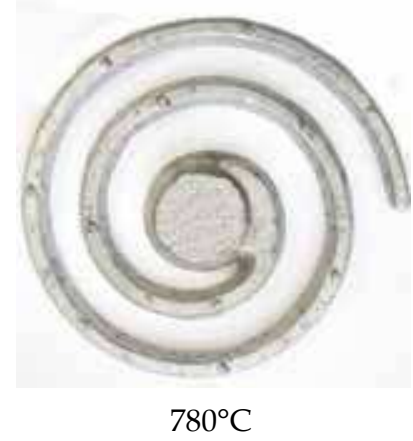

Spiral length $-0,57 \mathrm{~m}$

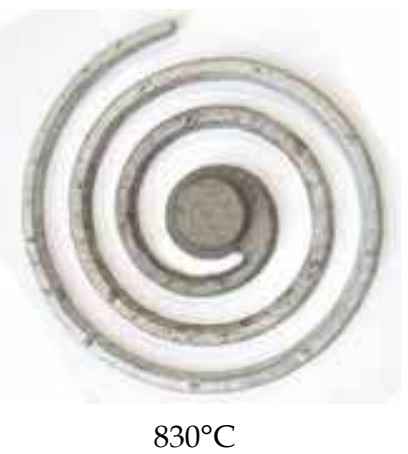

Spiral length $-0,73 \mathrm{~m}$

Fig. 4. Spiral casts of Elektron 21 alloy after fluidity test.

In Elektron 21 alloy after casting from $730^{\circ} \mathrm{C}$ the mean plane section area of a-Mg solid solution grains equals $\bar{A}=384 \mu \mathrm{m}^{2}$ and the mean area fraction of intermetallic phase is $\mathrm{A}_{\mathrm{A}}=3,2 \%$. Extension of the casting temperature to $780^{\circ} \mathrm{C}$ and $830^{\circ} \mathrm{C}$ brings slightly decrease of the mean plane section area of a-Mg grains respectively to $\bar{A}=375 \mu m^{2}$ and $\bar{A}=362 \mu m^{2}$, whereas the intermetallic phase quantity didn't change and equals $A_{A}=\sim 3,1 \%$, irrespective of casting temperature (Fig.5). 


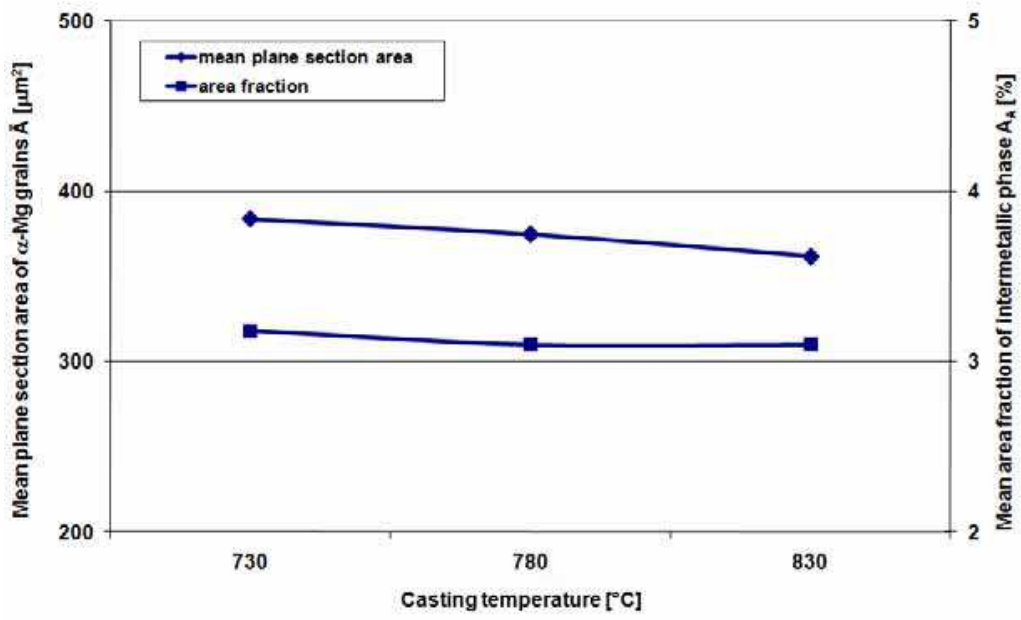

Fig. 5. The influence of casting temperature of Elektron 21 alloy on area fraction of the intermetallic phases and mean plane section area of a-Mg solid solution grains.

\subsection{Heat treatment}

\section{Solution treatment}

After solution treatment $520^{\circ} \mathrm{C} /$ water the $\mathrm{Mg}_{3}(\mathrm{Nd}, \mathrm{Gd})$ intermetallic phase dissolves in the matrix. 2-hours solution treatment causes a considerable ( $\sim$-times) decrease of the $\mathrm{Mg}_{3}(\mathrm{Nd}, \mathrm{Gd})$ phase area fraction to $\mathrm{A}_{\mathrm{A}}=1.93 \%$. The mean plane section area of a-Mg grains equals $\overline{\mathrm{A}}=2186 \mu \mathrm{m}^{2}$ and is higher (also $\sim 3$-times) compared to the as-cast state (Fig. 6a). Extension of the solution treatment time to $8 \mathrm{~h}$ brings about an even more considerable decrease of the phase area fraction to $A_{A}=0.66 \%$, whereas the mean plane section area of a-Mg grains grows to $\overline{\mathrm{A}}=3091 \mu \mathrm{m}^{2}$ (Fig.6b).

Extension of the solution treatment time to 24 hours brings about an even more considerable decrease of the $\mathrm{Mg}_{3}(\mathrm{Nd}, \mathrm{Gd})$ phase quantity to $\mathrm{A}_{\mathrm{A}}=0.5 \%$, whereas the grain size grows to $\overline{\mathrm{A}}$ $=3200 \mu \mathrm{m}^{2}$ (Fig.7a). Even longer solution treatment time (48h) caused precipitation of a NdGd intermetallic phase (probably $\mathrm{Nd}_{0.5} \mathrm{Gd}_{0.5}$ phase), however, it does not influence the solid solution grain mean area $\overline{\mathrm{A}}=3220 \mathrm{~m}^{2}$ (Fig.7b).

The influence of solution treatment time on the $\mathrm{Mg}_{3}(\mathrm{Nd}, \mathrm{Gd})$ phase quantity, the solid solution a-Mg grain size and hardness of Elektron 21 was presented on figures 8 and 9 . After short time of solutioning (2h) the hardness of Elektron 21 alloy increase to $67 \mathrm{HV}$ due to solution of neodymium and gadolinium in a-Mg matrix. Extension of the solution treatment time caused decreasing of hardness to $59 \mathrm{HV}$ due to grain size grows. After $48 \mathrm{~h}$ of solutioning, precipitation of a Nd-Gd intermetallic phase was observed which caused further decreasing of hardness to $47 \mathrm{HV}$. 


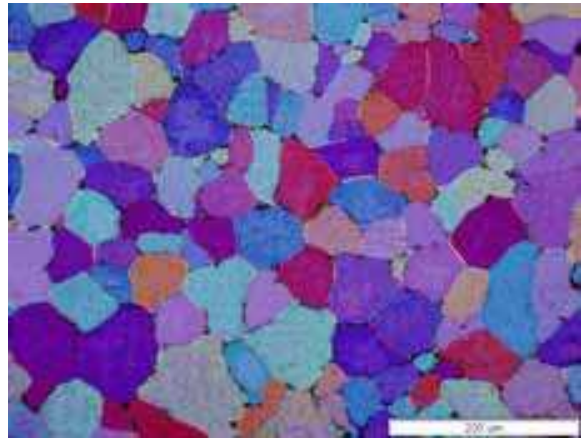

(a)

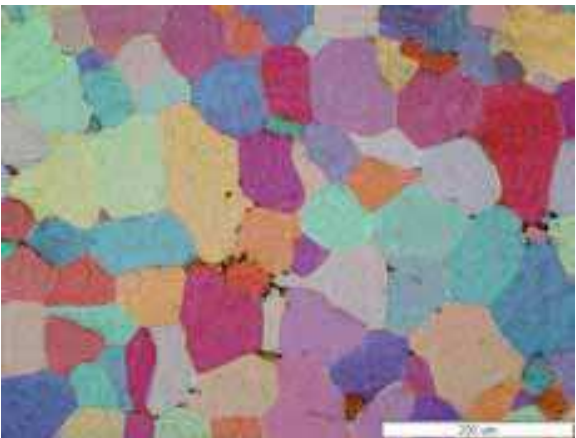

(b)

Fig. 6. Microstructure of Elektron 21 alloy after solution treatment a) $520^{\circ} \mathrm{C} / 2 \mathrm{~h} /$ water, b) $520^{\circ} \mathrm{C} / 8 \mathrm{~h} /$ water, $\mathrm{LM}$.

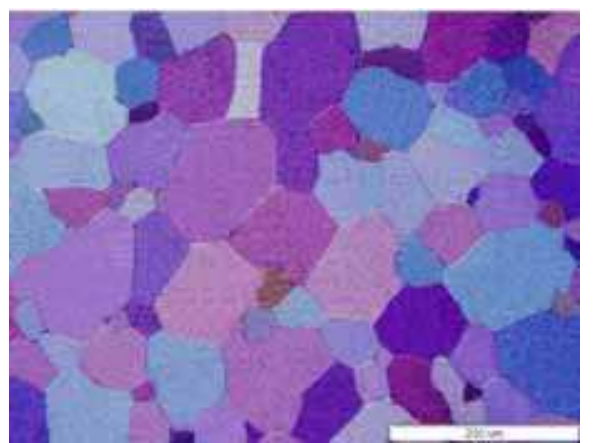

(a)

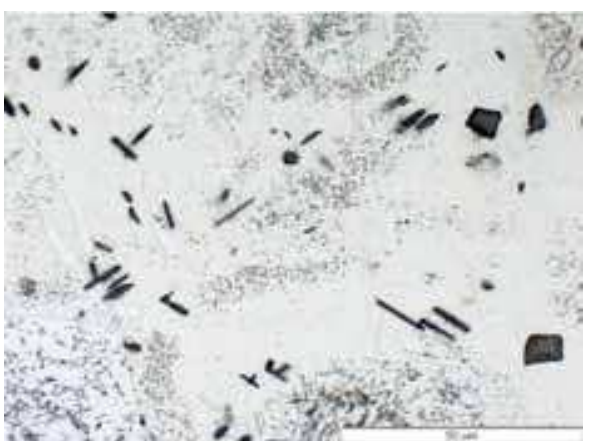

(b)

Fig. 7. Microstructure of Elektron 21 alloy after solution treatment a) $520^{\circ} \mathrm{C} / 24 \mathrm{~h} /$ water, b) $520^{\circ} \mathrm{C} / 48 \mathrm{~h} /$ water, $\mathrm{LM}$.

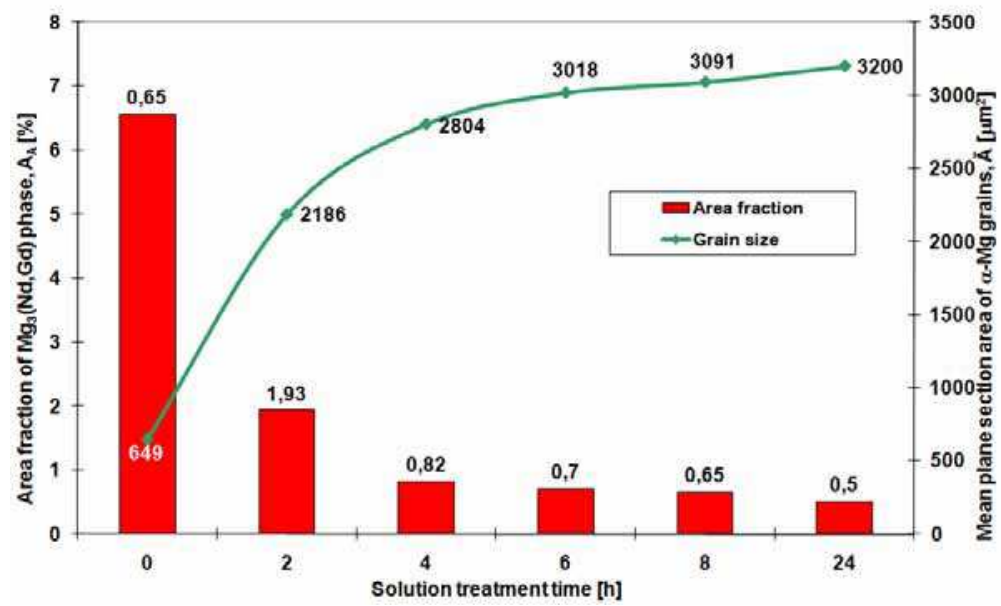

Fig. 8. Influence of the solution treatment time on the $\mathrm{Mg}_{3}(\mathrm{Nd}, \mathrm{Gd})$ phase quantity and the solid solution a-Mg grain size. 


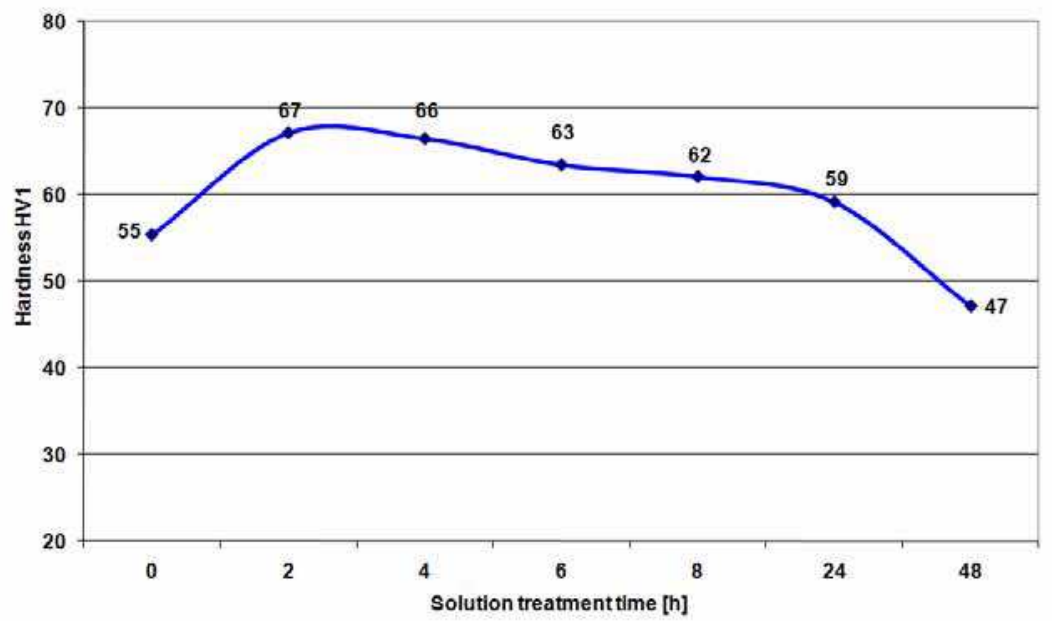

Fig. 9. Influence of the solution treatment time on the Elektron 21 hardness.

Ageing treatment

The microstructure of Elektron 21 alloy aged at $200{ }^{\circ} \mathrm{C}$ for $4 \mathrm{~h}$ contained thin precipitate platelets of $\beta^{\prime \prime}$ (Fig.10). The $\beta^{\prime \prime}$ platelets were approximately $8 \mathrm{~nm}$ in length and $2 \mathrm{~nm}$ thick. The $\beta^{\prime \prime}$ phase is fully coherent with the matrix. It has a $\mathrm{D}_{19}$ crystal structure $(\mathrm{a}=0,64 \mathrm{~nm}$ and $\mathrm{c}=0,52 \mathrm{~nm})$ and is isomorphous with the $\mathrm{Mg}_{3} \mathrm{X}(\mathrm{RE})$ phase.

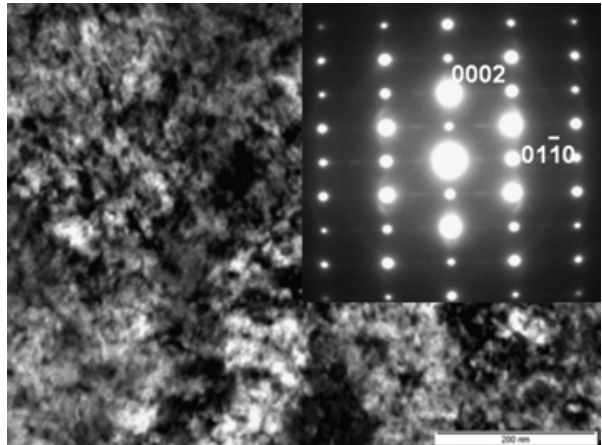

(a)

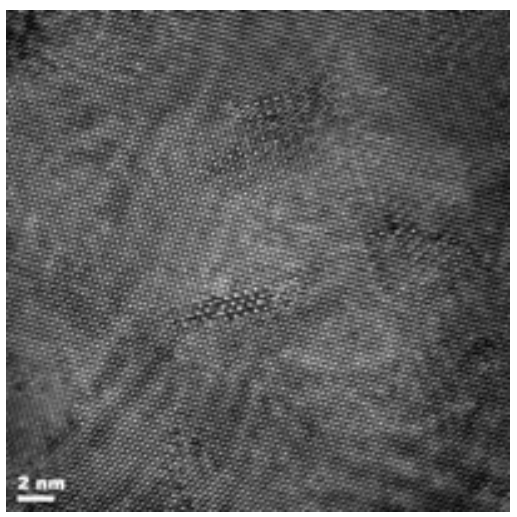

(b)

Fig. 10. Microstructure of the Elektron 21 alloy aged at $200^{\circ} \mathrm{C}$ for $4 \mathrm{~h}$ :

a) TEM image with corresponding (SAED) pattern, b) HRTEM image.

With continuous ageing for $16 \mathrm{~h}$ at $200{ }^{\circ} \mathrm{C}$ the microstructure contains except precipitates of $\beta^{\prime \prime}$, spherical particles of $\beta^{\prime}$ (Fig.11). The $\beta^{\prime}$ platelets were approximately $10 \div 15 \mathrm{~nm}$ in diameter and $<10 \mathrm{~nm}$ thick. The intermediate $\beta^{\prime}$ phase is metastable and semi coherent with the matrix. It has an orthorhombic crystal structure $(a=0,64 \mathrm{~nm}, b=2,22 \mathrm{~nm}$ and $c=0,52 \mathrm{~nm})$. 


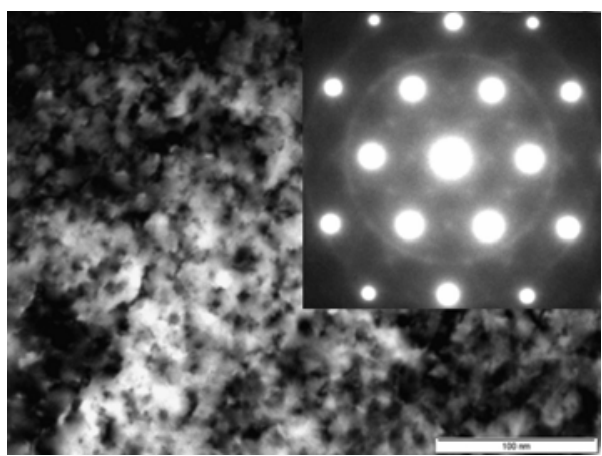

(a)

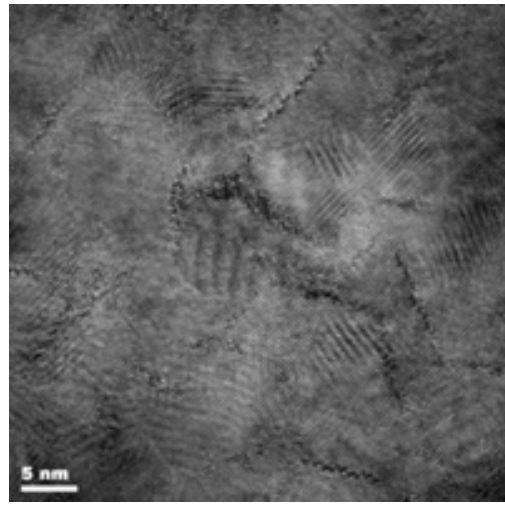

(b)

Fig. 11. Microstructure of the Elektron 21 alloy aged at $200^{\circ} \mathrm{C}$ for $16 \mathrm{~h}$ : a) TEM image with corresponding (SAED) pattern, b) HRTEM image.

The microstructure of Elektron 21 alloy aged at $200{ }^{\circ} \mathrm{C}$ for $48 \mathrm{~h}$ or aged at $250^{\circ} \mathrm{C}$ for $4 \mathrm{~h}$ consisted of enlarged $\beta^{\prime}$ phase precipitates and the elongated, needle-shaped precipitates of equilibrium $\beta$ phase (Fig.12). The precipitates of equilibrium $\beta$ phase were formed between the $\beta^{\prime}$ particles and nucleated preferentially in the strain field of the $\beta^{\prime}$ phase. This phase formed heterogeneously on $\beta^{\prime}$ particles. The $\beta$ phase is non-coherent with the a-Mg matrix and is identified as $\mathrm{Mg}_{3} \mathrm{Nd}$ phase. It has a face-centered cubic crystal structure $(\mathrm{a}=0.74 \mathrm{~nm})$. Similarly in as-cast condition $\mathrm{Mg}_{3} \mathrm{Nd}$ phase has the form of $(\mathrm{Mg})_{3}(\mathrm{Nd}, \mathrm{Gd})$.

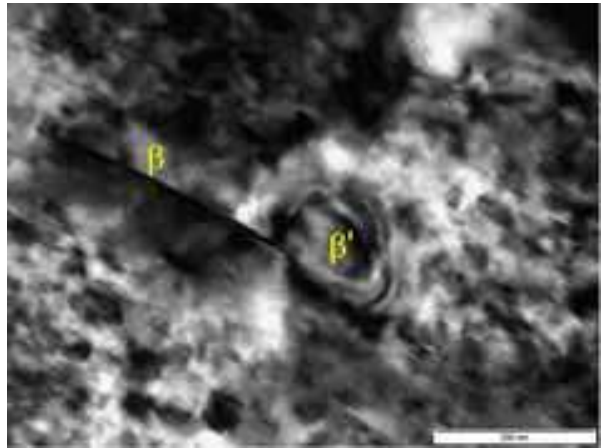

(a)

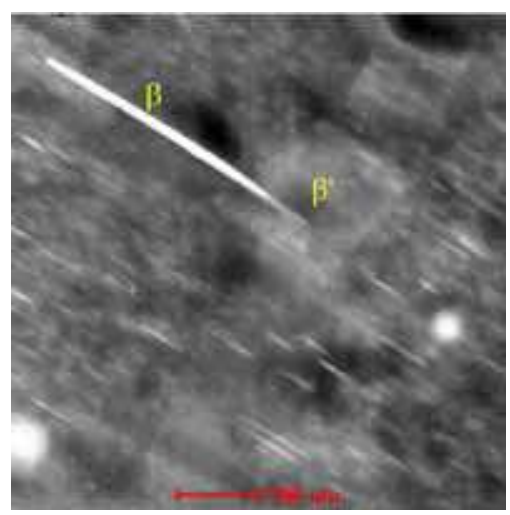

(b)

Fig. 12. Microstructure of the Elektron 21 alloy aged at $250^{\circ} \mathrm{C}$ for $4 \mathrm{~h}$ :

a) TEM image, b) STEM-HAADF image.

Ageing $\left(300^{\circ} \mathrm{C} / 500 \mathrm{~h}\right)$ caused the precipitation of the globular particles of $\mathrm{Mg}_{41} \mathrm{Nd}_{5}$ phase (Fig.13a,b). Precipitates of $\mathrm{Mg}(\mathrm{Nd}, \mathrm{Gd})_{3}$ phase have been also observed (Fig.13c). Longer annealing caused the formation of the network consisted of $\mathrm{Mg}_{41} \mathrm{Nd}_{5}$ precipitates on a-Mg solid solution grain boundaries. The hardness evolution, as a function of ageing time for isothermal ageing at 200, 250 and $300^{\circ} \mathrm{C}$ is shown in Fig. 14. 


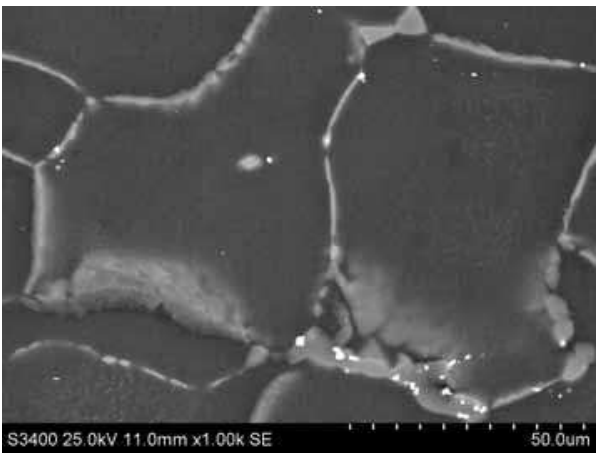

(a)

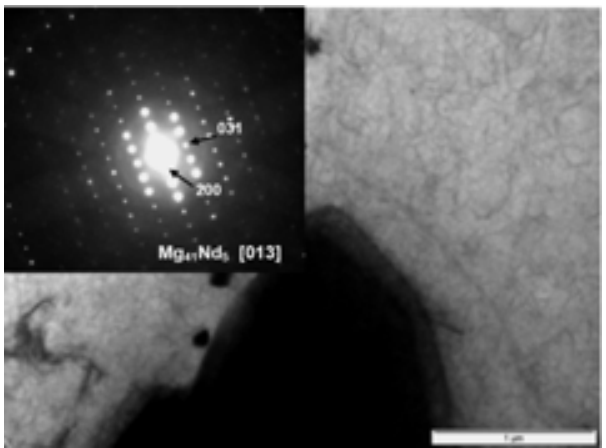

(c)

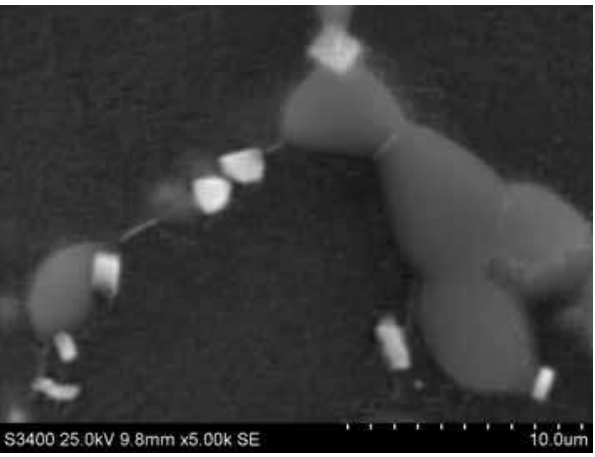

(b)

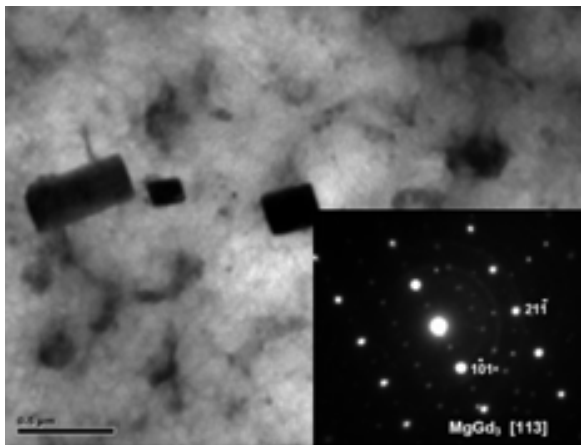

(d)

Fig. 13. Microstructure of the Elektron 21 alloy aged at $300^{\circ} \mathrm{C}$ for $500 \mathrm{~h}$ : a,b) SEM image ,d) TEM images

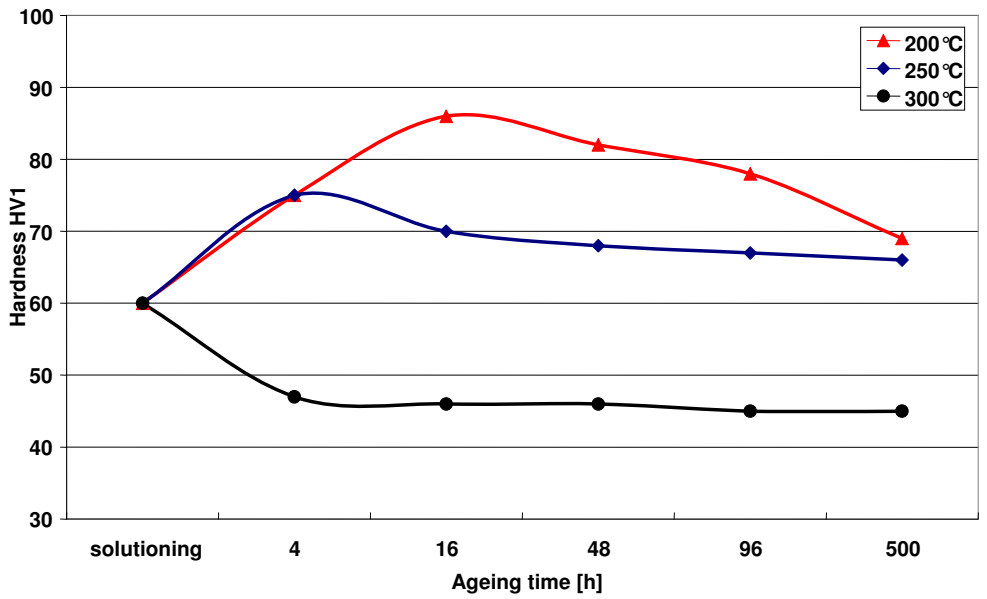

Fig. 14. Hardness evolution of the Elektron 21 alloy as a function of ageing time. 
Elektron 21 alloy showed a remarkable hardening at $200^{\circ} \mathrm{C}$ temperature, and the peak hardness value can reach $87 \mathrm{HV}$ after ageing for $16 \mathrm{~h}$ at $200{ }^{\circ} \mathrm{C}$ due to the precipitation of $\beta^{\prime \prime}$ and $\beta^{\prime}$ phases. The peak hardness was shortened with an increase of the ageing temperature. There wasn't any peak hardness in case of an alloy aged at $300^{\circ} \mathrm{C}$.

\subsection{Thermal diffusivity}

The temperature dependences of the thermal diffusivity for the Elektron 21 alloy in as-cast state and after heat treatment is shown in figure 15. The thermal diffusivity of solution treated Elektron 21 alloy was determinate only in the temperature range from room temperature to $200^{\circ} \mathrm{C}$. Above this temperature the influence of the phase transition on the thermal diffusivity is significant.

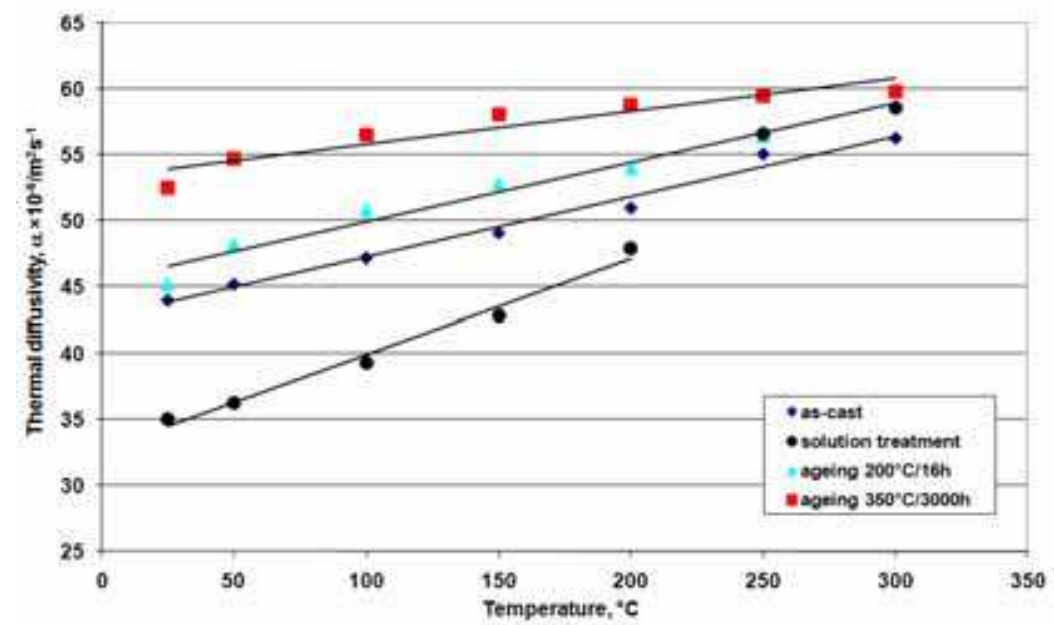

Fig. 15. Temperature dependence of the thermal diffusivity of Elektron 21 alloy, in as-cast condition and after heat treatment.

The thermal diffusivity of Elektron 21 alloy increase with the increase of temperature. The thermal diffusivity values $\left(\mathrm{m}^{2} \mathrm{~s}^{-1}\right)$ of this alloy are summarized in the following equations as a function of temperature.

Elektron 21 cast alloy

$$
\alpha=4,57 \times 10^{-2} \mathrm{~T}+42,68
$$

Elektron 21 solution-treated alloy

$$
\alpha=7,24 \times 10^{-2} \mathrm{~T}+32,66
$$

Elektron 21 aged at $200^{\circ} \mathrm{C} / 16 \mathrm{~h}$

$$
\alpha=4,51 \times 10^{-2} \mathrm{~T}+45,39
$$

Elektron 21 aged at $350^{\circ} \mathrm{C} / 3000 \mathrm{~h}$

$$
\alpha=2,5 \times 10^{-2} \mathrm{~T}+53,29
$$

Now we can discuss the influence of the content of the solute element in the a-Mg matrix on the thermal diffusivity of Elektron 21 alloy. This alloy after solution treatment showed low thermal diffusivity in this study because of its higher content of a solute element in the a-Mg 
matrix. The high-temperature-aged Elektron 21 alloy in which the strengthening phases precipitated exhibited higher thermal diffusivity than its solution-treated state. The secondary phase precipitation consumed solute elements in the a-Mg matrix, leading to increase the thermal diffusivity of this alloy.

\subsection{Creep properties}

Curves of creep tests at $200^{\circ} \mathrm{C}$ are presented in Fig. 16 and at $250^{\circ} \mathrm{C}$ are shown in Fig. 17. The creep curves at $200^{\circ} \mathrm{C}$ exhibit a well-defined primary and secondary stages.

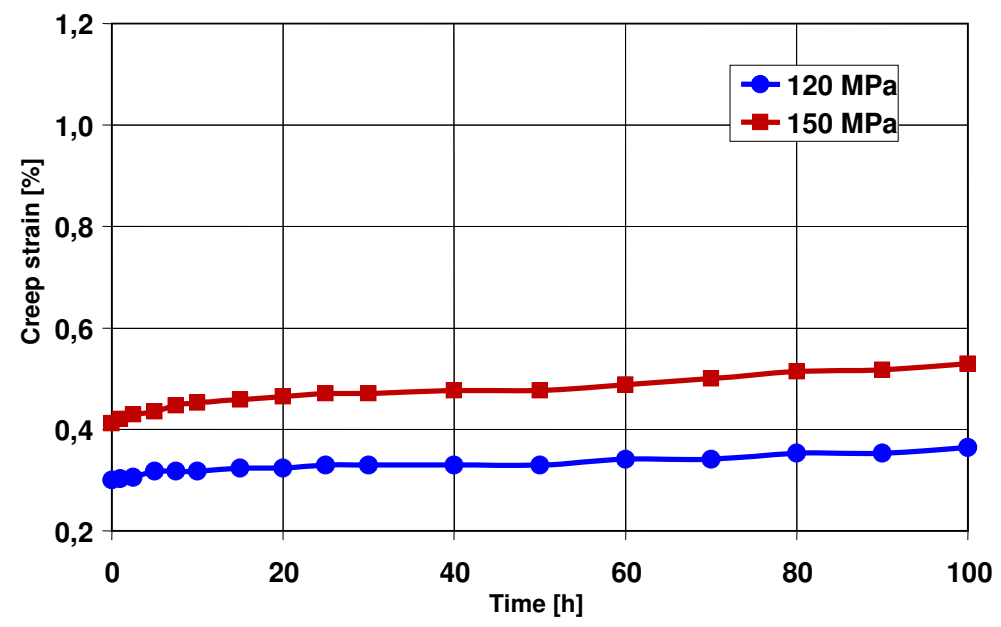

Fig. 16. Creep curves of Elektron 21 alloy (after T6 treatment) at $200^{\circ} \mathrm{C}$ under stresses of 120 and $150 \mathrm{MPa}$.

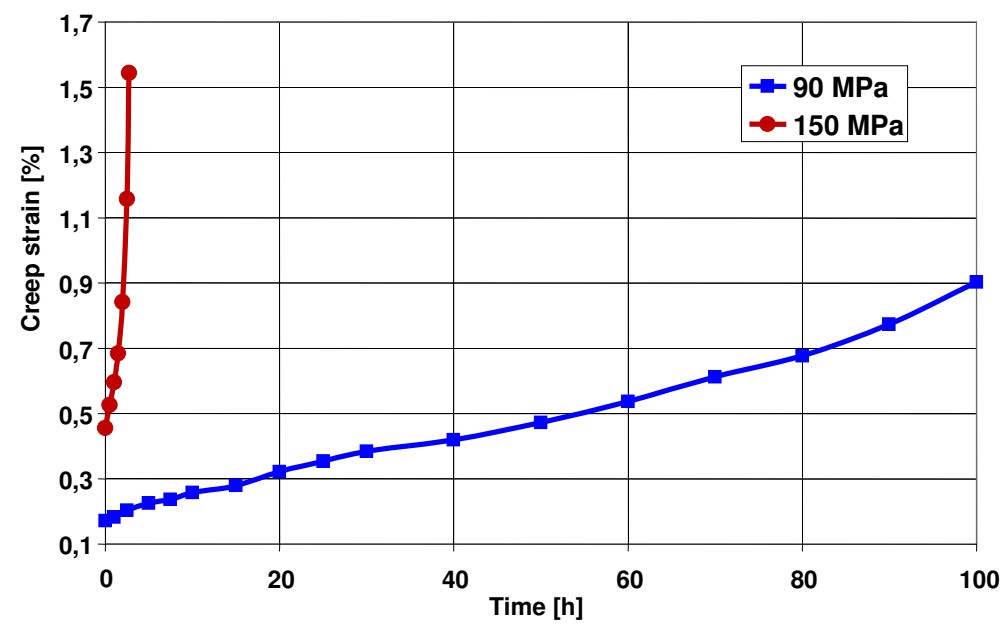

Fig. 17. Creep curves of Elektron 21 alloy (after T6 treatment) at $250^{\circ} \mathrm{C}$ under stresses of 120 and $150 \mathrm{MPa}$. 
The creep strain at $200^{\circ} \mathrm{C} / 100 \mathrm{~h}$ varies from $0.36 \%$ (120 MPa) to $0.53 \%$ (150 MPa). The strain of the samples, which were crept at $250^{\circ} \mathrm{C}$ and at $90 \mathrm{MPa}$ is equal $0.9 \%$, whereas the specimen crept at $250^{\circ} \mathrm{C}$ and at $150 \mathrm{MPa}$ has already ruptured after $2.7 \mathrm{~h}$. For this sample, only tertiary stage was observed (Fig. 17). From the gradient of the secondary stage in the creep curves, the steady-state creep rate can be calculated and the results are shown in Table 2. Obviously, the steady-state creep rate and creep strain increased with the increase of in the test temperature and applied stress. This fact suggests that a high dislocation generation rate surpasses the annihilation rate.

\begin{tabular}{|c|c|c|c|c|}
\hline & & $90 \mathrm{MPa}$ & $120 \mathrm{MPa}$ & $150 \mathrm{MPa}$ \\
\hline \multirow{2}{*}{$200^{\circ} \mathrm{C}$} & $\varepsilon[\%]$ & - & 0.36 & 0.53 \\
\cline { 2 - 5 } & $\dot{\varepsilon}[1 / \mathrm{s}]$ & - & $9.2 \cdot 10^{-10}$ & $2.3 \cdot 10^{-9}$ \\
\hline \multirow{2}{*}{$250^{\circ} \mathrm{C}$} & $\varepsilon[\%]$ & 0.9 & - & $1.54(2,7 \mathrm{~h})$ \\
\cline { 2 - 5 } & $\dot{\varepsilon}[1 / \mathrm{s}]$ & $1.7 \cdot 10^{-8}$ & - & - \\
\hline
\end{tabular}

Table 2. Creep elongation $\varepsilon$ and creep rate in the secondary stage $\dot{\varepsilon}$ of Elektron 21 alloy after $100 \mathrm{~h}$ of the test at different temperatures and stresses.

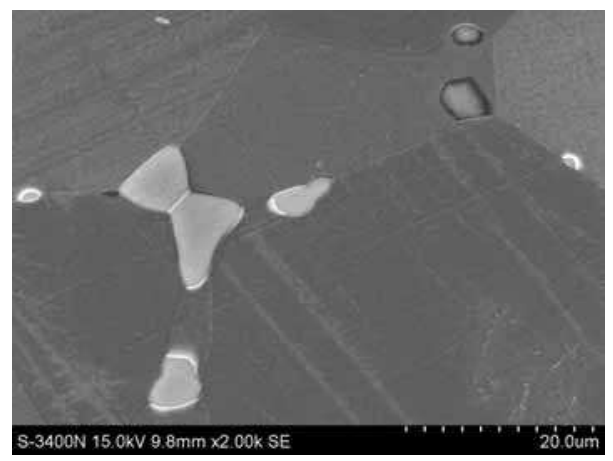

(a)

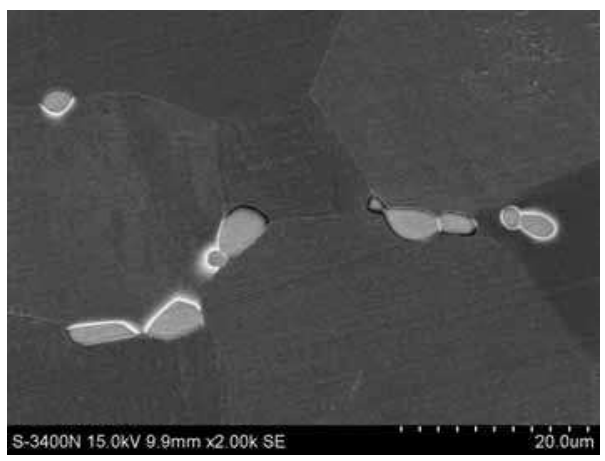

(b)

Fig. 18. The microstructure of the Elektron 21 alloy after creep test at $150 \mathrm{MPa} / 200^{\circ} \mathrm{C}$.

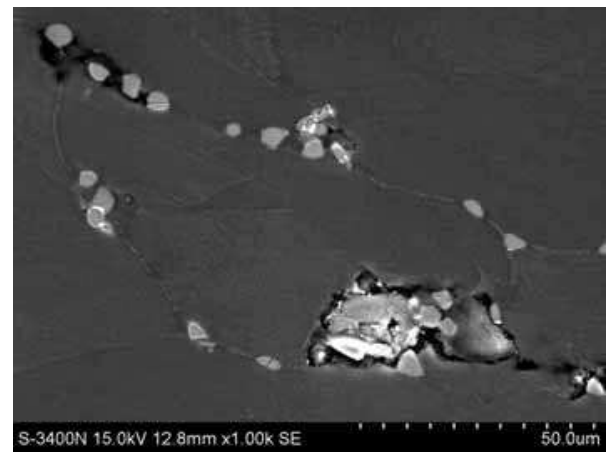

(a)

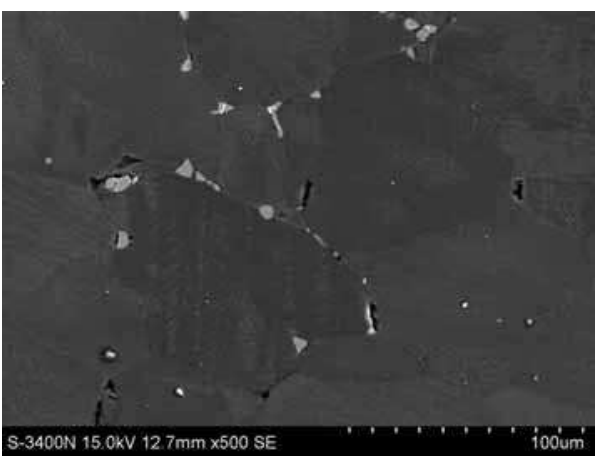

(b)

Fig. 19. The microstructure of the Elektron 21 alloy after creep test at $90 \mathrm{MPa} / 250^{\circ} \mathrm{C}$. 
The microstructure of Elektron 21 alloy after creep test at $200^{\circ} \mathrm{C} / 150 \mathrm{MPa}$ (the secondary stage) is presented in Fig. 18. It can be seen that undissolved particles of the $\mathrm{Mg}_{3}(\mathrm{Nd}, \mathrm{Gd})$ phase are present in the microstructure of this alloy after T6 treatment. The cracks in these particles and voids accumulated at the interfacial boundary between a-Mg and $\mathrm{Mg}_{3}(\mathrm{Nd}, \mathrm{Gd})$ are visible after creep at $200^{\circ} \mathrm{C} / 150 \mathrm{MPa}$. After creep test at $250^{\circ} \mathrm{C} / 90 \mathrm{MPa}$ (Fig. 19) numerous creep voids at the triple points are observed. Moreover, the large cracks, which were initiated under the stresses at the interfacial boundary are present in the microstructure of alloy investigated.

\subsection{Corrosion resistance}

Fig. 20 shows the typical surface features of the corroded specimens after 5 days of immersion test in $3.5 \% \mathrm{NaCl}$ saturated with $\mathrm{Mg}(\mathrm{OH})_{2}$ solution.

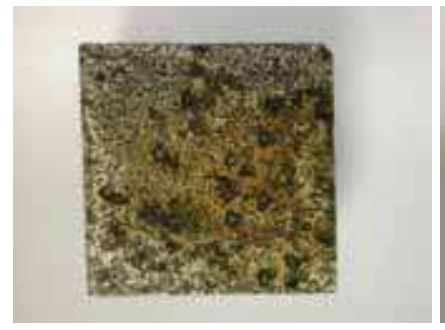

as cast

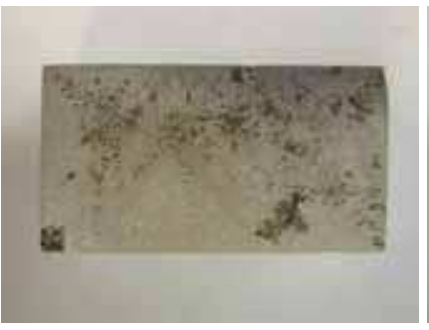

solutioning $520^{\circ} \mathrm{C} / 8 \mathrm{~h}$

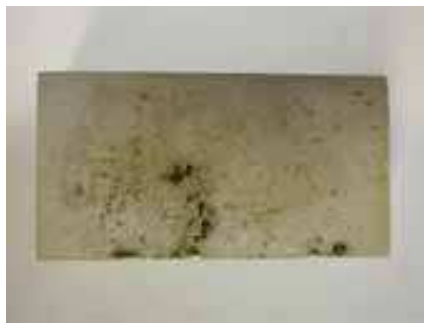

ageing $200^{\circ} \mathrm{C} / 4 \mathrm{~h}$

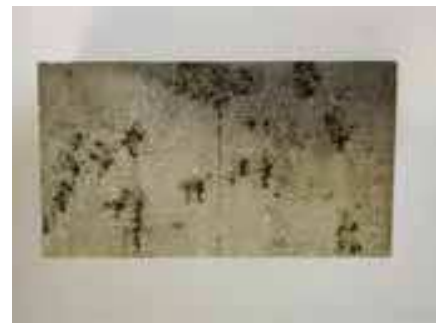

ageing $200^{\circ} \mathrm{C} / 16 \mathrm{~h}$

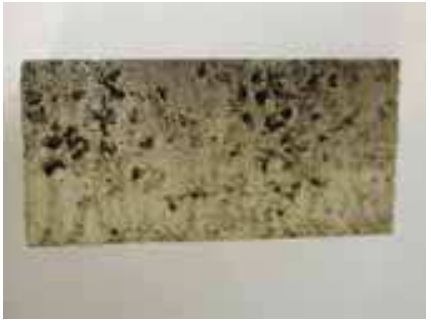

ageing $200^{\circ} \mathrm{C} / 48 \mathrm{~h}$

Fig. 20. Corrosion morphologies of Elektron 21 alloys before and after heat treatment after 5 days of immersion test in $3.5 \% \mathrm{NaCl}+\mathrm{Mg}(\mathrm{OH})_{2}$.

From the appearance of the specimen surface Elektron 21 in as-cast condition was more severely corroded than specimens after heat treatment. Only specimen after ageing $200^{\circ} \mathrm{C} / 48$ has similar morphology. The difference in macro-morphology of corroded specimens indicates different corrosion rates in dependence from heat treatment parameters. After five days, serious corrosion damage occurred on as cast state and aged $48 \mathrm{~h}$ alloy over its entire surface, whereas the corrosion of remaining specimens was only appeared on part of the specimen surface. The comparison of the corrosion rates results obtained from immersion test in 3.5\% $\mathrm{NaCl}$ are given in Fig. 21. 


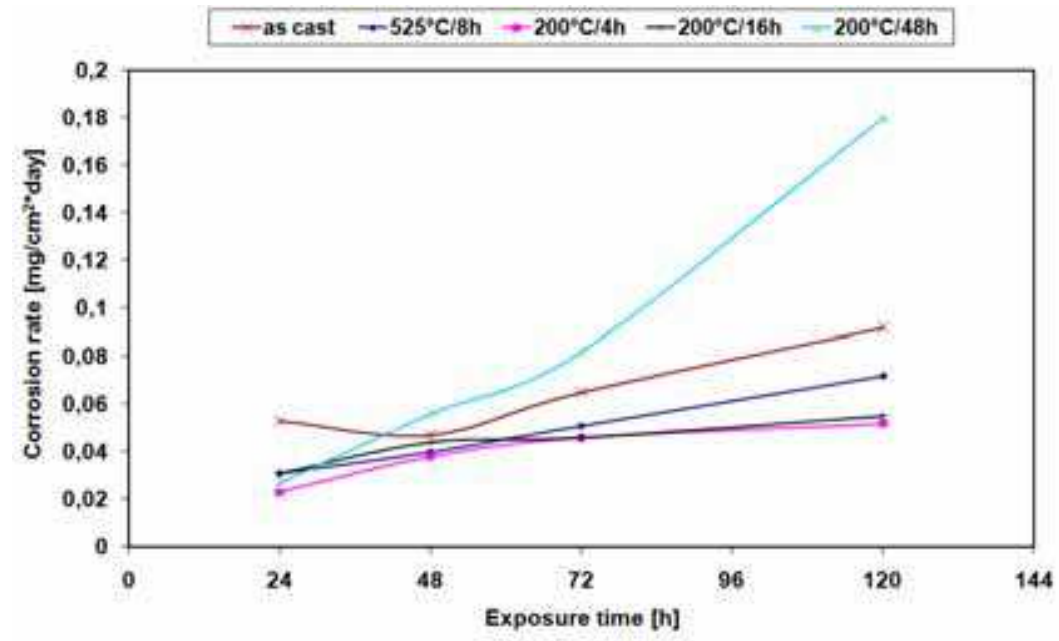

Fig. 21. Corrosion rates of Elektron 21 alloy before and after heat treatment during immersion test in $3.5 \% \mathrm{NaCl}+\mathrm{Mg}(\mathrm{OH})_{2}$.

Fig. 22 shows the effect of heat treatment on the corrosion resistance of Electron 21 alloy after exposure in $3.5 \% \mathrm{NaCl}+\mathrm{Mg}(\mathrm{OH})_{2}$ for 5 days.

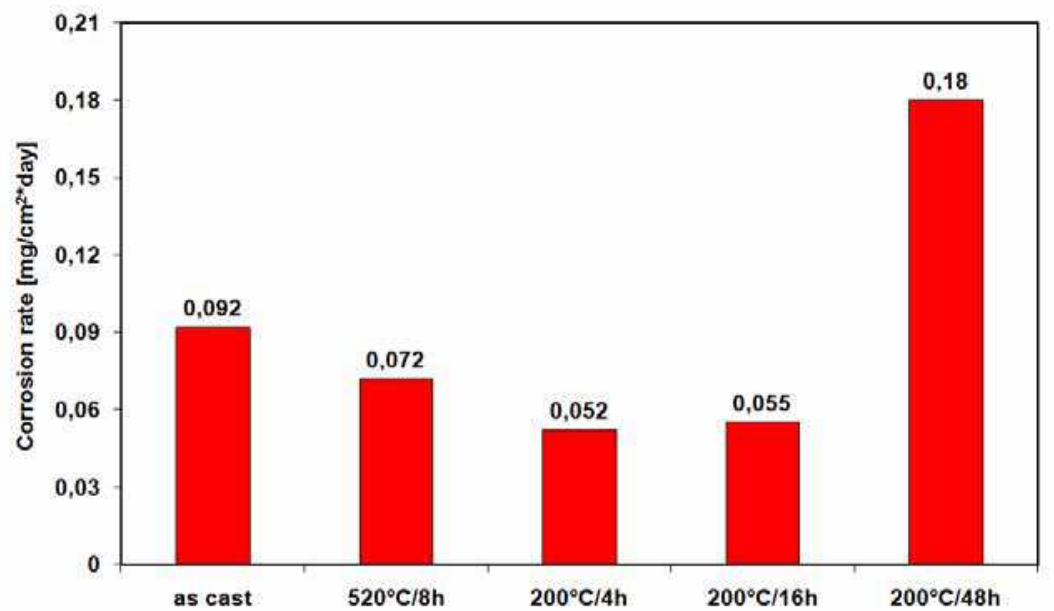

Fig. 22. Corrosion rates of Elektron 21 alloy after immersion test in $3.5 \% \mathrm{NaCl}+\mathrm{Mg}(\mathrm{OH})_{2}$ for 5 days.

The corrosion rates of Elektron 21 alloy incresed with the increase of the exposure time and finally (after 5 days) reached maximum value $0.092 \mathrm{mg} / \mathrm{cm}^{-2}$ day $^{-1}$. After solution treatment $\left(520^{\circ} \mathrm{C} / 8 \mathrm{~h}\right)$, the corrosion rate decrease due to dissolved of intermetallic phase precipitates and reached maximum value $0.072 \mathrm{mg} \mathrm{cm}^{-2} \mathrm{day}^{-1}$. Ageing at $200^{\circ} \mathrm{C}$ for $4 \mathrm{~h}$ and $16 \mathrm{~h}$ caused only slightly decrease of corrosion rate to value 0.052 and $0.055 \mathrm{mg} \mathrm{cm}^{-2} \mathrm{day}^{-1}$, respectively, due to precipitations of $\beta^{\prime}$ phase. While after ageing for $48 \mathrm{~h}$ the corrosion rate considerably 
increase to value $0.188 \mathrm{mg} \mathrm{cm}^{-2} \mathrm{day}^{-1}$ due to increase of the volume fraction and size of $\beta^{\prime}$ phase and precipitations of equilibrium $\beta$ phase.

The corrosion propagation was most uniform for the solution treatment condition. Corrosion rate decreases due to dissolution of intermetallic phase. Aged specimens (4h and 16h) were less corroded than as-cast alloy, and the difference in corrosion damage depends on ageing time. With increased ageing time, the volume fraction of precipitates increased gradually and these particles behaved as the cathodic sites and thus matrix attack is favored by micro galvanic cell formation.

\section{Summary}

The Elektron 21 alloy in as-cast condition is characterized by a solid solution structure a-Mg with eutectic a-Mg $+\mathrm{Mg}_{3}(\mathrm{Nd}, \mathrm{Gd})$ intermetallic phase on grain boundaries and precipitates of $\mathrm{Mg}(\mathrm{Nd}, \mathrm{Gd})_{3}$. The castability of this alloy increase linearly with the increase of casting temperature over the whole temperature range. The increasing of the casting temperature causes slightly decrease of the mean plane section area of a-Mg solid solution grains whereas the volume fraction of the intermetallic phases didn't change.

The hardness of Elektron 21 alloy increase to $67 \mathrm{HV}$ after $2 \mathrm{~h}$ of solutioning in $520^{\circ} \mathrm{C}$ due to solution of neodymium and gadolinium in a-Mg matrix. Extension of the solution treatment time caused decreasing of hardness to $59 \mathrm{HV}$ due to the mean plane section area of a-Mg solid solution grains grows and decrease of the area fraction of $\mathrm{Mg}_{3}(\mathrm{Nd}, \mathrm{Gd})$ phase. After $48 \mathrm{~h}$ of solutioning precipitation of a Nd-Gd intermetallic phase was observed which caused further decreasing of harness to $47 \mathrm{HV}$.

In first stage of ageing process the product of the $\mathrm{a}-\mathrm{Mg}$ decomposition are fully coherent and semi-coherent with the matrix precipitates of $\beta^{\prime \prime}$ and $\beta^{\prime}$ phases, respectively. It causes an increase of hardness and the peak hardness ( $87 \mathrm{HV})$ was observed after $16 \mathrm{~h}$ of ageing at $200^{\circ} \mathrm{C}$. Second stage is the formation of a stable equilibrium $\beta\left(\mathrm{Mg}_{3} \mathrm{Nd}\right)$ phase. The $\beta$ phase is non-coherent with the $\mathrm{a}-\mathrm{Mg}$ matrix. Further ageing led to decrease of the hardness. The last stage of ageing assigned to formation of $\mathrm{Mg}_{41} \mathrm{Nd}_{5}$ phase. Long term annealing at $300^{\circ} \mathrm{C} / 500 \div 5000 \mathrm{~h} /$ air caused precipitation of globular $\mathrm{Mg}_{41} \mathrm{Nd}_{5}$ phases on solid solution grain boundaries. Also precipitates of $\mathrm{Mg}(\mathrm{Nd}, \mathrm{Gd})_{3}$ phase have been observed. The hardness of Elektron 21 alloy decrease to $45 \mathrm{HV}$ after $500 \mathrm{~h}$ of annealing due to precipitation of these phases. Even longer annealing time $(2000 \div 5000 \mathrm{~h})$ caused formation the network of $\mathrm{Mg}_{41} \mathrm{Nd}_{5}$ precipitatates on solid solution grain boundaries. However, it hasn't significant influence on the mean plane section area of a-Mg grains $\left(\overline{\mathrm{A}}=\sim 3200 \mu \mathrm{m}^{2}\right)$, the area fraction of $\mathrm{Mg}_{41} \mathrm{Nd}_{5}$ phase $\mathrm{A}_{\mathrm{A}}=\sim 5,5 \%$ and hardness $44 \mathrm{HV}$

Generally, the investigated alloy showed that the decomposition of a-Mg supersaturated solid solution with increasing ageing time is as follows:

$$
\mathrm{a}-\mathrm{Mg} \rightarrow \beta^{\prime \prime} \rightarrow \beta^{\prime} \rightarrow \beta\left(\mathrm{Mg}_{3} \mathrm{RE}\right) \rightarrow \mathrm{Mg}_{41} \mathrm{Nd}_{5} .
$$

The thermal diffusivity of Elektron 21 alloys was temperature and microstructure dependent. It was dependent on the content of the solute element in the a-Mg matrix. The solid solution of $\mathrm{Nd}$ and $\mathrm{Gd}$ in $\mathrm{Mg}$ has lower thermal diffusivity than alloy where the intermetallic $\mathrm{Mg}_{3}(\mathrm{Nd}, \mathrm{Gd})$ phase is present. The formation of strengthening phases during ageing caused the consumption of the solute element in the a -Mg matrix, and improved the thermal conductivity of the alloy. The results confirm that the thermal diffusivity of Elektron 21 alloy depend on its thermal history. 
Also corrosion behaviour of Elektron 21 alloy strongly depends on heat treatment condition. Corrosion rate of solutioned specimen is lower than those for as-cast due to dissolution of intermetallic phase precipitates and solution hardening. Lower corrosion rate of Elektron 21 alloy after short period of ageing $(4 \mathrm{~h}, 16 \mathrm{~h})$ is caused by precipitation of metastable $\beta^{\prime}$ phase. Higher corrosion rate of Elektron 21 alloy after ageing treatment at $200^{\circ} \mathrm{C}$ for $48 \mathrm{~h}$ is caused by increase of $\beta^{\prime}$ size and its volume fraction and also due precipitation of equilibrium $\beta$ phases in microstructure.

\section{Acknowledgement}

The present work was supported by the Polish Ministry of Science and Higher Education under the research projects No N N507 451334 and PBR N R15-0015-04/2008.

\section{References}

He S.M., Zeng X.O., Peng L.M., Gao X., Nie J.F., Ding W.J., (2006). Precipitation in a Mg10Gd-3Y-0.4Zr (wt.\%) alloy during isothermal ageing at $250^{\circ} \mathrm{C}$, eburnal of Alloys and Compounds, Vol. 421 (2006), pp. 309-313.

Lyon P., Syed I., Wilks T., (2005). The influence of alloying elements and heat treatment upon properties of Elektron 21 (EV31A) alloy, Magnesium Technology 2005, pp. 303308 .

Rokhlin L., Nikitina N., Dobatkina T., (1996). Solid-state phase equilibria in the Mg corner of the Mg-Gd-Sm phase diagram, eburnal of Alloys and Compounds, Vol. 239, (1996) pp. 209-213.

Smola B., Stulikova I., von Buch F., Mordike B., (2002),.Structural aspects of high performance Mg alloy design, Materials Science and Engineering A Vol. 324, (2002), pp. 113-117.

Mordike B., Eberr T., (2001). Magnesium: Properties-applications-potentials, Materials Science and Engineering A, Vol. 302, Issue 1 (2001) pp.37-45.

Mordike B., (2002). Creep-resistant magnesium alloys, Materials Science and Engineering A, Vol. 324 (2002), pp.103-112

Avedesian M., Baker H., (1994). Magnesium and Magnesium Alloys, ASM Speciality Handbook, ASM International, The Materials Information Society (1994).

Mordike B., (2001). Development of highly creep resistant magnesium alloys, eburnal of Material Processing Technology Vol. 117 (2001), pp.391-394.

Lorimer G., Apps P., Karimzadech H., King J., (2003). Improving the performance of MgRare Earth alloys by the use of Gd or Dy additions. Materials Science Forum Vols. 419-422 (2003), pp.279-284. 


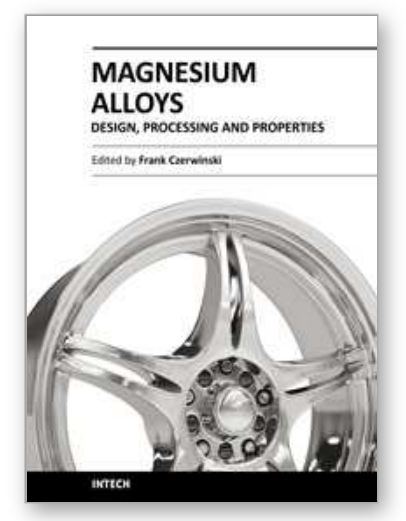

\author{
Magnesium Alloys - Design, Processing and Properties \\ Edited by Frank Czerwinski
}

ISBN 978-953-307-520-4

Hard cover, 526 pages

Publisher InTech

Published online 14, January, 2011

Published in print edition January, 2011

Scientists and engineers for decades searched to utilize magnesium, known of its low density, for lightweighting in many industrial sectors. This book provides a broad review of recent global developments in theory and practice of modern magnesium alloys. It covers fundamental aspects of alloy strengthening, recrystallization, details of microstructure and a unique role of grain refinement. The theory is linked with elements of alloy design and specific properties, including fatigue and creep resistance. Also technologies of alloy formation and processing, such as sheet rolling, semi-solid forming, welding and joining are considered. An opportunity of creation the metal matrix composite based on magnesium matrix is described along with carbon nanotubes as an effective reinforcement. A mixture of science and technology makes this book very useful for professionals from academia and industry.

\title{
How to reference
}

In order to correctly reference this scholarly work, feel free to copy and paste the following:

Andrzej Kielbus (2011). Microstructure and Properties of Elektron 21 Magnesium Alloy., Magnesium Alloys Design, Processing and Properties, Frank Czerwinski (Ed.), ISBN: 978-953-307-520-4, InTech, Available from: http://www.intechopen.com/books/magnesium-alloys-design-processing-and-properties/microstructure-andproperties-of-elektron-21-magnesium-alloy-

\section{INTECH}

open science | open minds

\author{
InTech Europe \\ University Campus STeP Ri \\ Slavka Krautzeka 83/A \\ 51000 Rijeka, Croatia \\ Phone: +385 (51) 770447 \\ Fax: +385 (51) 686166 \\ www.intechopen.com
}

\author{
InTech China \\ Unit 405, Office Block, Hotel Equatorial Shanghai \\ No.65, Yan An Road (West), Shanghai, 200040, China \\ 中国上海市延安西路65号上海国际贵都大饭店办公楼405单元 \\ Phone: +86-21-62489820 \\ Fax: +86-21-62489821
}


(C) 2011 The Author(s). Licensee IntechOpen. This chapter is distributed under the terms of the Creative Commons Attribution-NonCommercialShareAlike-3.0 License, which permits use, distribution and reproduction for non-commercial purposes, provided the original is properly cited and derivative works building on this content are distributed under the same license. 